\title{
ANALISIS PENGARUH HARGA CRUDE PALM OIL (CPO) DUNIA TERHADAP NILAI TUKAR RIIL RUPIAH
}

\author{
Hilda Aprina, SST
}

\begin{abstract}
Indonesia is a biggest producer of Crude Palm Oil (CPO) in the world. Production and export volumes continued to increase from year to year. CPO products have an important role in the Indonesian economy, one of them as the country's largest foreign exchange earner in the plantation sector. Given that Indonesia has adopted a floating exchange rate regime since 1978, the export of commodities such as palm oil will have an important influence on the real exchange rate. Therefore, this study aimed to see how much the world price of CPO influence the development of the real exchange rate of rupiah. The analytical method used is a simultaneous equation model using time series data from 1984 to 2011. The results showed that the increase in CPO price will lead to real exchange rate rupiah appreciated. Therefore, Indonesia as a major producer of CPO should be able to control the world price of crude palm oil in order to control the stability of the real exchange rate of the rupiah
\end{abstract}

Keywords : world CPO price, simultaneous equation model, the real exchange rate of rupiah.

\section{JEL Classification: E2}

1 Hilda is working at BPS (Badan Pusat Statistik) Jakarta, Indonesia; hildaaprina@ymail.com Received: January $24^{\text {th }}, 2014$. Accepted for Publication : October $2^{\text {nd }}, 2014$ 


\section{PENDAHULUAN}

Indonesia dikenal sebagai negara agraris karena mengandalkan sektor pertanian baik sebagai sumber mata pencaharian maupun sebagai penopang pembangunan. Subsektor perkebunan yang merupakan salah satu bagian dari pertanian memiliki laju pertumbuhan PDB yang tinggi, pada tahun 2011 laju pertumbuhannya mencapai 4,47 persen. ${ }^{2}$

Berdasarkan data Direktorat Jenderal Perkebunan, dari sembilan komoditas unggulan perkebunan, kelapa sawit menempati urutan pertama dalam ekspor di tahun 2011 sebesar 53,57 persen dengan nilai 17,23 miliar dolar AS.Kelapa sawit merupakan salah satu komoditas perkebunan yang memberikan kontribusi paling besar untuk devisa Indonesia, karena tanaman perkebunan ini memiliki nilai ekonomis yang cukup tinggi dan merupakan salah satu tanaman penghasil minyak nabati.

Peran penting komoditas kelapa sawit menurut Susila dalam publikasi BPS (2008) adalah memberikan kontribusi yang besar bagi perekonomian Indonesia melalui ekspor, seperti pengurangan kemiskinan dan penciptaan lapangan kerja baru. Produk kelapa sawit yaitu minyak sawit/Crude Palm Oil (CPO) merupakan bahan utama salah satu energi alternatif yang digunakan sebagai pengganti minyak bumi, yaitu energi biodiesel. Hal ini tentu akan berpengaruh terhadap besarnya permintaan CPO dunia.

\begin{tabular}{|c|c|c|c|c|c|c|c|}
\hline \multicolumn{8}{|c|}{$\begin{array}{c}\text { Tabel } 1 \\
\text { Negara Produsen Utama CPO Dunia Tahun 2005-2011 (000 Ton) }\end{array}$} \\
\hline \multirow{2}{*}{ Tahun } & \multicolumn{7}{|c|}{ Volume (000 Ton) } \\
\hline & 2005 & 2006 & 2007 & 2008 & 2009 & 2010 & 2011 \\
\hline 1 & 2 & 3 & 4 & 5 & 6 & 7 & 8 \\
\hline Indonesia & 14070 & 14962 & 16800 & 19200 & 21000 & 22100 & 23900 \\
\hline Malaysia & 14962 & 15881 & 15823 & 17735 & 17566 & 16993 & 18800 \\
\hline Thailand & 680 & 860 & 1020 & 1300 & 1310 & 1380 & 1830 \\
\hline Nigeria & 800 & 815 & 835 & 830 & 870 & 885 & 900 \\
\hline Columbia & 661 & 713 & 780 & 778 & 802 & 753 & 765 \\
\hline Equador & 319 & 345 & 385 & 418 & 448 & 380 & 460 \\
\hline Negara Lain & 2559 & 2478 & 2905 & 3045 & 3107 & 3367 & 4159 \\
\hline
\end{tabular}

2 BPS. (2013). Produk Domestik Bruto Atas Dasar Harga Berlaku Menurut Lapangan Usaha (Miliar Rupiah), 2004-2012. http://www. bps.go.id/tab_sub/view.php?kat=2 \&tabel=1\& daftar=1\&id_subyek $=11 \&$ notab=1. [1 Juli 2013]. 
Sejak tahun 1984 ekspor kelapa sawit Indonesia mulai stabil dan terus mengalami peningkatan beberapa tahun berikutnya. Namun, pada saat itu Malaysia masih menguasai pangsa ekspor dunia. Memasuki tahun 1990, pangsa ekspor Indonesia maupun Malaysia terus meningkat. Akan tetapi, pada tahun 1995 pangsa ekspor Malaysia mulai menurun sementara ekspor Indonesia terus tumbuh. Hingga akhirnya Indonesia bisa menjadi produsen CPO terbesar di dunia, mengungguli Malaysia. Produksi CPO Indonesia pada tahun 2011 mencapa 23,9 juta ton yang merupakan angka terbesar di dunia. Selain itu, Indonesia juga memiliki pangsa ekspor CPO terbesar di dunia. Dengan demikian seharusnya Indonesia dapat menjadi patokan harga CPO dunia.

Dengan kontribusinya yang cukup besar dibandingkan dengan komoditi lain, harga dunia CPO dinilai dapat mempengaruhi pergerakan nilai tukar riil rupiah. Mengingat sejak 1977 Indonesia telah menganut sistem nilai tukar mengambang, sehingga peran komoditas ekspor semakin penting dalam pergerakan nilai tukar.Grafik 1 menunjukkan hubungan antara pergerakan nilai tukar riil rupiah dengan perkembangan harga CPO internasional.

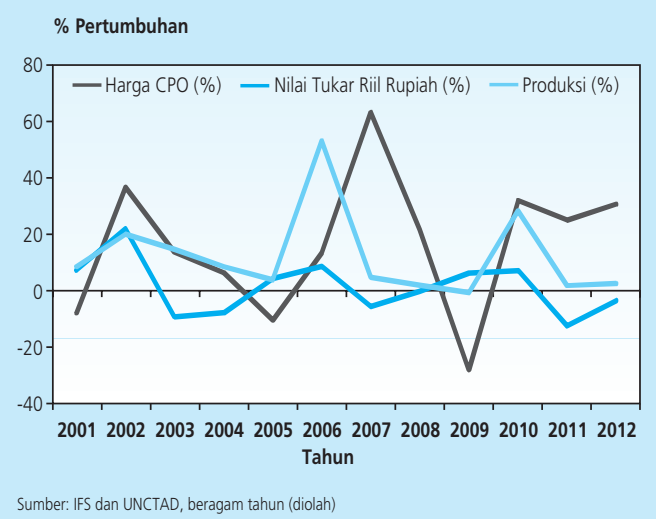

Grafik 1. Persentase Pertumbuhan Nilai Tukar Riil Rupiah, Harga CPO Dunia dan Produksi CPO Indonesia Tahun 20002011(Persen)

Menurut Sebastian Edwards (1986), perubahan pada harga komoditi ekspor utama umumnya memiliki efek penting terhadap perilaku nilai tukar baik secara langsung maupun melalui sektor moneter. Beberapa penelitian yang pernah dilakukan sebelumnya hanya sebatas untuk melihat pengaruh nilai tukar rupiah terhadap ekspor CPO. Oleh sebab itu, pada penelitian ini akan mencoba untuk mengetahui sejauh mana perubahan harga domestik dan internasional CPO mempengaruhi nilai tukar riil rupiah. Studi ini membatasi penelitian hanya pada komoditas CPO dengan kode HS 1511110000, dan pada periode tahun 1984 hingga 2011. 
Berdasarkan uraian diatas, penelitian ini akan mengkaji apakah perubahan pada harga dunia CPO akan memengaruhi nilai tukar riil. Penelitian ini mencoba untuk menganalisis seberapa besar pengaruh harga dunia CPO terhadap perubahan nilai tukar riil rupiah melalui perubahan uang beredar serta inflasi. Selain itu, penelitian ini juga akan memberikan gambaran CPO sebagai komoditas ekspor unggulan.

\section{TEORI}

Menurut Edward (1987) perubahan harga komoditi ekspor suatu negara memiliki pengaruh penting terhadap pergerakan nilai tukar riil. Pada kondisi tertentu, seperti ledakan komoditas ekspor akan menghasilkan apresiasi nilai tukar riil negara tersebut. Perubahan harga komoditas ekspor ini juga memiliki pengaruh penting dalam pada sektor moneter, bagaimanapun efek ini secara tidak langsung juga akan berdampak pada pergerakan nilai tukar riil.

Chen dan Rogoff (2003) membuktikan adanya hubungan antara tingkat nilai tukar dan komoditas ekspor. Mereka menemukan bahwa nilai tukar riil Australia dan New Zealand didorong oleh harga komoditas dunia. Hasilnya konsisten dengan analisis yang dilakukan oleh Cashin, Cespedes dan Sahay (2004), mereka memberikan tambahan bukti bagi negara berkembang. Dalam kasus di Afrika Selatan, Frankel (2007) menunjukkan bahwa mineral adalah salah satu komoditi ekspor yang harganya memiliki pengaruh penting dalam penentuan nilai tukar riil di negara tersebut. Hal ini juga dikonfirmasi oleh Ngandu (2005) yang melakukan penelitian pustaka mengenai hubungan antara harga komoditas ekspor dan perubahan tingkat nilai tukar riil sebagian besar terjadi di negara berkembang.

Kelapa sawit merupakan komoditas utama sektor perkebunan dan salah satu komoditas unggulan Indonesia karena kontribusinya terhadap perolehan devisa, peluang pengembangan pasar serta penyerapan tenaga kerja. ${ }^{2}$ CPO memiliki peran yang sangat penting dalam perekonomian makro Indonesia. Hal ini dapat dilihat dari besarnya kontribusi komoditas ini terhadap nilai PDB, penyerapan tenaga kerja hingga penciptaan devisa negara. Perdagangan minyak sawit maupun olahannya menjadi sumber pendapatan negara kedua terbesar dari sektor nonmigas. Besarnya sumber pendapatan negara melalui perdagangan CPO ini nantinya akan meningkatkan pertumbuhan uang beredar di dalam negeri. Menurut Boediono (1993) apabila neraca pembayaran mengalami surplus, berarti ada devisa yang masuk ke dalam negara, hal ini berarti ada penambahan jumlah uang beredar. Sehingga melalui peningkatan harga CPO dunia, maka akan meningkatkan pendapatan negara yang diikuti oleh penambahan jumlah uang beredar.

Ketika jumlah uang beredar meningkat, maka akan terjadi perubahan harga barang. Hal ini sesuai dengan teori kuantitas uang yang merupakan teori hubungan langsung antara

2 BPS.(2008). Kajian Komoditas Unggulan. Jakarta: BPS. 
perubahan jumlah uang yang beredar dengan perubahan harga barang. Hubungan tersebut dapat dikemukakan bahwa harga barang berbanding lurus dengan jumlah uang yang beredar. (Dornbush, 2001, hal 373).

\section{$M \times V=P \times Y$}

Dimana:

$\mathrm{M}=$ Money in circulation (jumlah uang yang beredar)

$\mathrm{P}=$ Price (tingkat harga barang)

$\mathrm{V}=$ Perputaran uang

$Y=$ Harga

Pada umumnya, untuk mengukur tingkat harga rata-rata, para ekonom menyusun suatu indeks harga yang merata-rata harga komoditi yang berbeda menurut seberapa penting komoditi tersebut. Indeks tersebut dikenal sebagai Consumer Price Index (CPI) atau Indeks Harga Konsumen (IHK) (Lipsey, 1995). Menurut Samuelson dan Nordhaus (2004, hal 391), inflasi diakibatkan oleh cost push inflation dan demand pull inflation. Ketika terjadi peningkatan uang beredar, maka akan menyebabkan terjadinya demand pull inflation.

Demand pull inflation bermula dari adanya kenaikan permintaan agregat dalam kondisi kesempatan kerja penuh (full employment) yang menyebabkan terjadinya excess demand di pasar. Apabila kesempatan kerja penuh telah tercapai, penambahan permintaan selanjutnya hanyalah akan menaikkan harga saja (sering disebut dengan inflasi murni). Hal ini disebabkan oleh ekspansi kebijakan moneter, seperti peningkatan belanja negara dan peningkatan jumlah uang beredar dimana tingkat permintaan barang menjadi tinggi sedangkan persediaan barang relatif tetap.

Faktor penyebab terjadi demand pull inflation adalah tingginya permintaan barang dan jasa relatif terhadap ketersediaannya. Dalam konteks makroekonomi, kondisi ini digambarkan oleh output riil yang melebihi output potensialnya atau permintaan total (aggregate demand) lebih besar daripada kapasitas perekonomian. Sementara itu, faktor ekspektasi inflasi dipengaruhi oleh perilaku masyarakat dan pelaku ekonomi apakah lebih cenderung bersifat adaptif atau forward looking.

Menurut Muqrobi (2011), terjadinya inflasi akan menurunkan pertumbuhan output yang selanjutnya akan mengurangi impor dan dorongan permintaan valas sehingga rupiah akan terapresiasi. Pengertian nilai tukar rupiah suatu mata uang dapat dilihat dalam dua aspek, yaitu aspek nominal dan aspek riil. Nilai tukar nominal menyatakan nilai tukar domestik per nilai tukar asing. Nilai tukar nominal yang umum adalah nilai tukar bilateral di mana terdapat dua negara, misal rupiah per dolar Amerika Serikat (AS). Sedangkan nilai tukar riil adalah nilai tukar nominal yang telah disesuaikan dengan tingkat harga. Secara lebih spesifik, hubungan 
antara nilai tukar nominal dan nilai tukar riil dapat ditunjukkan secara matematika dengan formula berikut ini:

$$
\mathbf{R E R}=\mathbf{e} \mathbf{x} \frac{\boldsymbol{P}^{*}}{\boldsymbol{P}}
$$

$$
\begin{array}{ll}
\text { Dimana: } & \\
\operatorname{RER} & =\text { nilai tukar riil } \\
\mathrm{e} & =\text { nilai tukar nominal } \\
\mathrm{P}^{*} & =\text { tingkat harga luar negeri } \\
\mathrm{P} & =\text { tingkat harga dalam negeri }
\end{array}
$$

Persamaan di atas mengimplikasikan bahwa apabila nilai tukar riil terapresiasi, maka harga produk domestik relatif menjadi lebih mahal dan harga produk luar negeri menjadi lebih murah. Sebaliknya, apabila nilai tukar riil terdepresiasi, maka harga produk domestik menjadi lebih murah dan harga produk luar negeri menjadi lebih mahal. Hal ini menjadikan nilai tukar riil sebagai tolak ukur daya saing produk ekspor suatu negara dalam hal harga di pasar global.

\section{Faktor -faktor Penentu Kurs Riil}

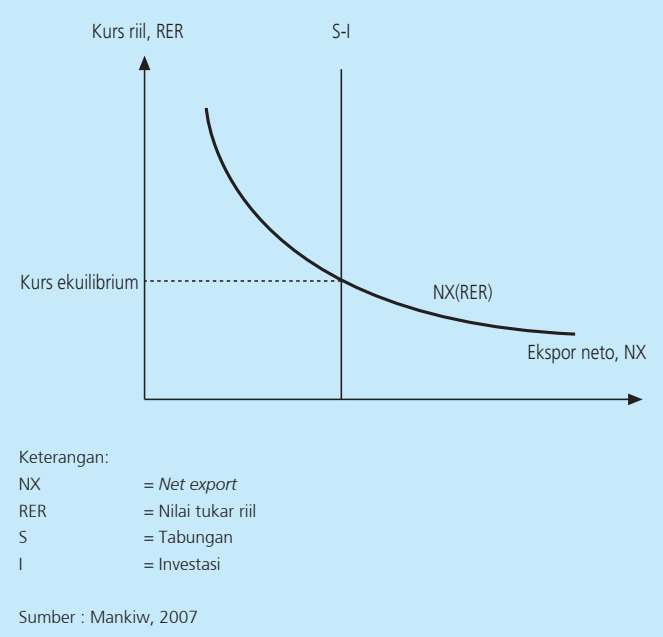

Grafik 2. Faktor penentu kurs riil 
Grafik di atas menunjukkan hubungan antara ekspor neto dan kurs riil memiliki slope negatif karena semakin rendah kurs riil membuat harga barang-barang domestik relatif lebih murah. Garis yang menunjukkan selisih antara tabungan dengan investasi (S-I) terlihat vertikal karena tidak dipengaruhi oleh kurs (Mankiw, 2007, hal 131). Kurs yang digunakan pada grafik di atas adalah nilai mata uang dolar AS terhadap mata uang luar negeri, sehingga dalam penelitian ini arahnya jadi berbeda. Jika kurs mengalami depresiasi, yaitu nilai mata uang dalam negeri menurun dan berarti nilai mata uang asing bertambah tinggi kursnya (harganya) akan menyebabkan ekspor meningkat dan impor cenderung menurun. Jadi, kurs valuta asing mempunyai hubungan yang searah dengan volume ekspor, dan kurs dalam negeri mempunyai hubungan yang searah dengan volume impor.

\section{METODOLOGI}

\subsection{Model Persamaan Simultan}

Sifat dasar dari model persamaan simultan berdasarkan penjelasan Gujarati (2004), ada hubungan dua arah (simultan) antara satu atau beberapa variabel penjelas, yang membuat perbedaan antara variabel tak bebas dan variabel yang menjelaskan menjadi meragukan. Karena itu, lebih baik untuk mengumpulkan bersama-sama sejumlah variabel yang dapat ditentukan secara simultan oleh kumpulan variabel sisanya. Model seperti ini ada lebih dari satu persamaan, satu untuk tiap variabel tak bebas, atau bersifat endogen atau gabungan, atau bersama. Tidak seperti model persamaan tunggal, dalam model persamaan simultan parameter dari satu persamaan tunggal tidak mungkin ditaksir tanpa memperhitungkan informasi yang diberikan oleh persamaan lain dalam sistem.

Variabel dalam model persamaan simultan terdiri dari dua jenis: bersifat endogen, yaitu variabel-variabel yang nilainya ditetapkan di dalam model; dan predeterminded (ditetapkan lebih dulu), yaitu variabel yang nilainya ditetapkan di luar model. Variabel predeterminded dibagi dalam dua kategori: bersifat eksogen, baik saat ini maupun lag, dan yang bersifat endogen lag, dimana ketiga variabel tersebut nilainya tidak ditetapkan oleh model dalam periode saat ini, namun dianggap ditetapkan lebih dahulu (Gujarati, 2004).

Persamaan yang dibentuk di dalam suatu model ekonomi dikenal sebagai persamaan yang bersifat struktural atau bersifat behavioral (perilaku), karena persamaan tersebut menggambarkan struktur dari suatu model ekonomis dari suatu ekonomi atau perilaku dari pelaku ekonomi. Menurut Gujarati (2004) bentuk struktural dari model persamaan simultan yang berupa sistem persamaan, pada umumnya dapat ditulis sebagai berikut: 


$$
\begin{aligned}
Y_{1 t}=\beta_{11} Y_{1 t} & +\beta_{12} Y_{2 t}+\cdots+\beta_{1 M} Y_{M t}+\gamma_{11} X_{1 t}+\gamma_{12} X_{2 t}+\cdots+\gamma_{1 k} X_{k t} \\
& +u_{1 t} \\
Y_{2 t}=\beta_{21} Y_{1 t} & +\beta_{22} Y_{2 t}+\cdots+\beta_{2 M} Y_{M t}+\gamma_{21} X_{1 t}+\gamma_{22} X_{2 t}+\cdots+\gamma_{2 k} X_{k t} \\
& +u_{2 t} \\
Y_{3 t}=\beta_{31} Y_{1 t} & +\beta_{32} Y_{2 t}+\cdots+\beta_{3 M} Y_{M t}+\gamma_{31} X_{1 t}+\gamma_{32} X_{2 t}+\cdots+\gamma_{3 k} X_{k t} \\
& +u_{3 t} \\
Y_{M t}=\beta_{M 1} Y_{1 t} & +\beta_{M 2} Y_{2 t}+\cdots+\beta_{M M} Y_{M t}+\gamma_{M 1} X_{1 t}+\gamma_{M 2} X_{2 t}+\cdots+\gamma_{M k} X_{k t} \\
& +u_{M t}
\end{aligned}
$$

Dimana:

$Y_{1}, Y_{2}, \ldots, Y_{M} \quad=$ variabel independen atau variabel endogen sebanyak $M$ buah,

$\mathrm{X}_{1}, \mathrm{X}_{2}, \ldots, \mathrm{X}_{\mathrm{K}} \quad=$ variabel eksogen (predetermined) sebanyak $\mathrm{K}$ buah,

$U_{1}, U_{2}, \ldots, U_{M} \quad$ = variabel disturbansi (galat) sebanyak $M$ buah,

$\mathrm{t}=1,2, \ldots, \mathrm{M} \quad$ = jumlah observasi,

$\beta \quad$ = koefisien variabel endogen,

$\gamma \quad=$ koefisien variabel eksogen.

Penentuan variabel manakah yang dianggap eksogen dan endogen, tergantung kepada preferensi peneliti, namun tetap berpijak pada landasan teori yang mendasari pembangunan model tersebut. Model persamaan yang digunakan pada penelitian ini merupakan persamaan yang dibangun oleh Sebastian Edward (1987). Dalam model ini, nilai tukar riil (RER) dijadikan variabel endogenus karena variabel ini dianggap bergantung pada nilai inflasi domestik, dunia dan harga CPO dunia. Beberapa penelitian terdahulu juga mengasumsikan nilai tukar riil sebagai variable endogenous, karena nilai tukar riil secara cepat beraksi terhadap beberapa shock. Sebagaimana Brischetto, Voss (1999) dan Berkelmans (2005) menyelesaikan teka-teki nilai tukar dengan memasukkan variabel harga komoditas unggulan.

\subsection{Data dan Spesifikasi Model}

Dalam analisis ini digunakan data sekunder berupa data runtun waktu (time series).Data nilai tukar nominal rupiah terhadap dolar $\mathrm{AS}(\mathrm{E})$, uang beredar $\left(\mathrm{M}_{2}\right)$, Produk Domestik Bruto (PDB), Indeks Harga Konsumen (IHK) dan Indeks Harga Produsen (IHP) diperoleh dari International Financial Statistics (IFS). Sementara data harga CPO dunia diperoleh dari UNCTAD dan data defisit anggaran diperoleh dari Departemen Keuangan. 
Pada penelitian ini, perumusan model ekonometrika yang dibangun didasarkan pada kerangka teori ekonomi dan fakta empiris yang menunjukkan pengaruh dari pertumbuhan harga CPO dunia terhadap pertumbuhan uang beredar, inflasi domestik, dan pertumbuhan nilai tukar riil. Model yang digunakan pada penelitian ini merupakan model yang dibangun oleh Sebastian Edward (1987):

1. Fungsi Pertumbuhan Uang

$$
\begin{aligned}
\operatorname{Ln}\left(M_{t}\right)=\alpha_{0} & +\alpha_{1} \operatorname{Ln}\left(M_{t-1}\right)+\alpha_{2} \operatorname{Ln}\left(D E H_{t}\right)+\alpha_{3}\left(\operatorname{Ln}\left(R E R_{t}\right)+\operatorname{Ln}\left(P_{t}^{c *}\right)\right) \\
& +v_{1 t}
\end{aligned}
$$

Tanda yang diharapkan $\alpha_{1}>0, \alpha_{2}>0$, dan $\alpha_{3}>0$

2. Fungsi Inflasi

$$
P_{t}=\delta_{0}+\delta_{1} \operatorname{Ln}\left(M_{t}\right)+\delta_{2} y_{t}+\alpha_{3}\left(\operatorname{Ln}\left(R E R_{t}\right)+P_{t}^{*}\right)+v_{2 t}
$$

Tanda yang diharapkan $\delta_{1}>0, \delta_{2}>0$, dan $\delta_{3}>0$

3. Fungsi Nilai Tukar Riil

$$
\operatorname{Ln}\left(R E R_{t}\right)=\mu_{0}+\mu_{1} P_{t}+P_{t}^{*}+\mu_{3} \operatorname{Ln}\left(P_{t}^{c *}\right)+v_{3 t}
$$

Tanda yang diharapkan $\mu 1<0, \mu_{2}>0$, dan $\mu_{3}<0$

Keterangan:

$\mathrm{M}_{\mathrm{t}}=$ Jumlah uang beredar periode tahun $\mathrm{t}$

$\mathrm{M}_{\mathrm{t}-1}=$ Jumlah uang beredar periode tahun sebelumnya

$\mathrm{DEH}_{\mathrm{t}}=$ Defisit anggaran periode tahun $\mathrm{t}$

$\mathrm{P}_{\mathrm{t}}^{\mathrm{c} *}=$ Harga $\mathrm{CPO}$ dunia periode tahun $\mathrm{t}$

$\mathrm{P}_{\mathrm{t}} \quad=$ Inflasi domestik periode

$Y \quad=$ Pertumbuhan Ekonomi

$\mathrm{P}_{\mathrm{t}}^{*}=$ Inflasi dunia periode tahun $\mathrm{t}$

$\mathrm{v}_{\text {it }} \quad=$ Error term persamaan i periode tahun $\mathrm{t}$

Dummy ; $\quad>$ Tahun $1997=1$

$$
<\text { Tahun } 1997=0
$$




\subsection{Simulasi Model}

Sitepu dan Sinaga (2006) menjabarkan bahwa simulasi adalah bagian integral dari pengembangan keakuratan model-model yang bertujuan untuk menangkap perilaku suatu data historis (historical data). Simulasi yang dilakukan pertama sekali bertujuan untuk mencari model yang tepat, bagaimana perubahan variabel endogen sebagai suatu fungsi dari satu atau lebih variabel eksogen, dimana ketepatan ini ditentukan oleh validasi model yang dilakukan sebelumnya. Apabila suatu model yang tepat atau sesuai ditemukan, maka model persamaan tersebut dapat digunakan untuk melakukan simulasi atau meramalkan nilai-nilai variabel endogen dengan nilai tertentu variabel-variabel eksogen.

Penelitian ini melakukan simulasi pada variabel eksogen, yaitu harga CPO dunia yang disimulasikan naik sebesar 10 dan 20 persen. Simulasi ini menggunakan data historikal tahun 1984-2011.

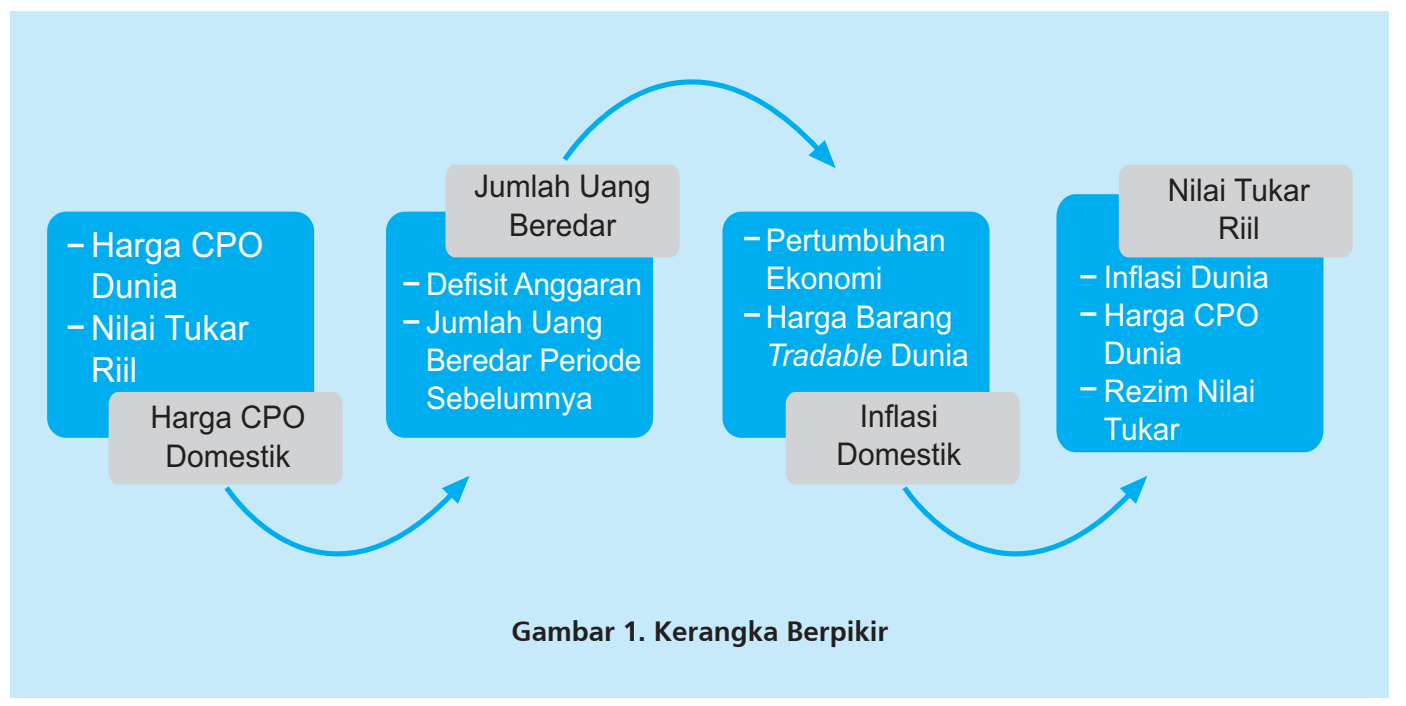

Crude Palm Oil (CPO) merupakan salah satu komoditi yang memimpin ekspor nonmigas Indonesia. Saat ini Indonesia merupakan produsen utama CPO mengalahkan Malaysia. Selain itu, CPO merupakan komoditas utama ekspor pertanian Indonesia. Pergerakan harga CPO dunia mempengaruhi nilai ekspor Indonesia. Semakin tinggi harga CPO dunia, semakin tinggi pula cadangan devisa yang dihasilkan. Kemudian kenaikan harga CPO domestik dapat mempengaruhi peningkatan uang beredar di tangan masyarakat. Hal ini dapat menimbulkan inflasi yang akhirnya memengaruhi apresiasi nilai tukar riil rupiah. 


\section{HASIL DAN ANALISIS}

\subsection{CPO Sebagai Komoditas Ekspor Unggulan}

Kelapa sawit merupakan komoditas utama sektor perkebunan dan salah satu komoditas unggulan Indonesia karena kontribusinya terhadap perolehan devisa, peluang pengembangan pasar serta penyerapan tenaga kerja (BPS, 2008). Peran penting komoditas kelapa sawit menurut Susila dalam publikasi BPS (2008), adalah memberikan kontribusi yang sangat signifikan terhadap pertumbuhan ekonomi, adanya pengurangan kemiskinan serta perbaikan ekonomi yang terbuka.

Salah satu produk kelapa sawit yaitu CPO, memiliki peran yang sangat penting dalam perekonomian makro Indonesia. Hal ini dapat dilihat dari besarnya kontribusi komoditas ini terhadap nilai PDB, penyerapan tenaga kerja hingga penciptaan devisa negara. Perdagangan minyak sawit maupun olahannya menjadi sumber pendapatan negara kedua terbesar dari sektor nonmigas.

CPO merupakan bahan utama salah satu energi alternatif yang digunakan sebagai pengganti minyak bumi, yaitu energi biodiesel. Hal ini tentu akan berpengaruh terhadap permintaan CPO dunia. Dari total minyak sawit yang diperdagangkan, minyak sawit Indonesia memiliki pangsa cukup besar dalam perdagangan internasional.

Pada grafik 3 di bawah dapat dilihat dari total produk kelapa sawit yang diperdagangkan. Produk CPO memiliki persentase yang tinggi sejak tahun 1990, sekitar 40 persen dari total perdagangan. Hal ini membuktikan bahwa Indonesia lebih banyak mengekspor CPO mentah daripada produk turunan kelapa sawit lainnya. Dapat dilihat pada grafik di bawah bahwa Indonesia mengekspor lebih dari 50 persen CPO mentah dibandingkan produk olahannya. Timpangnya struktur industri kelapa sawit, membuat nilai tambahnya tidak maksimal.

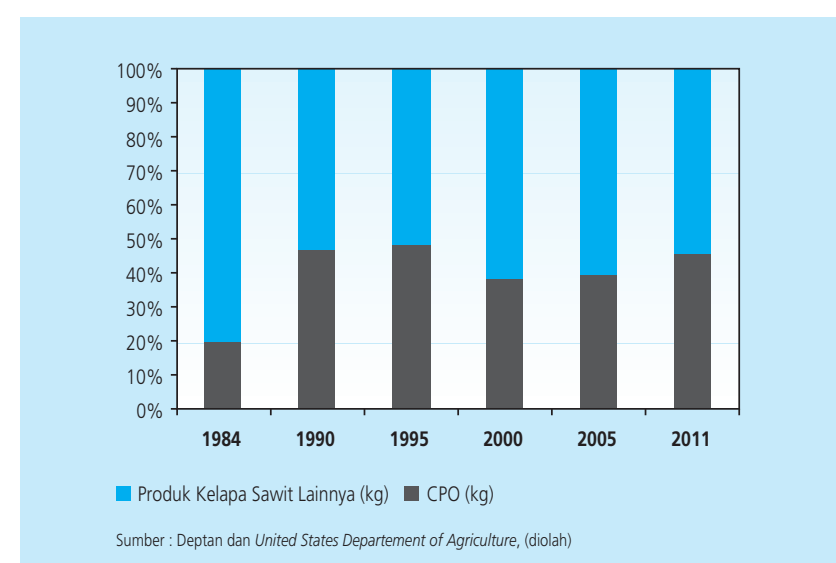

Grafik 3. Presentase Ekspor CPO (Persen) 
Sebagai komoditas ekspor yang memiliki nilai ekonomis tinggi, CPO dianggap sebagai pencipta devisa negara yang paling stabil karena nilai perdagangannya selalu surplus. Selain itu, besarnya konsumsi domestik terhadap komoditas ini juga dapat mempengaruhi jumlah uang beredar dalam masyarakat, jika dilihat lebih lanjut hal ini dapat berpengaruh terhadap peningkatan inflasi.

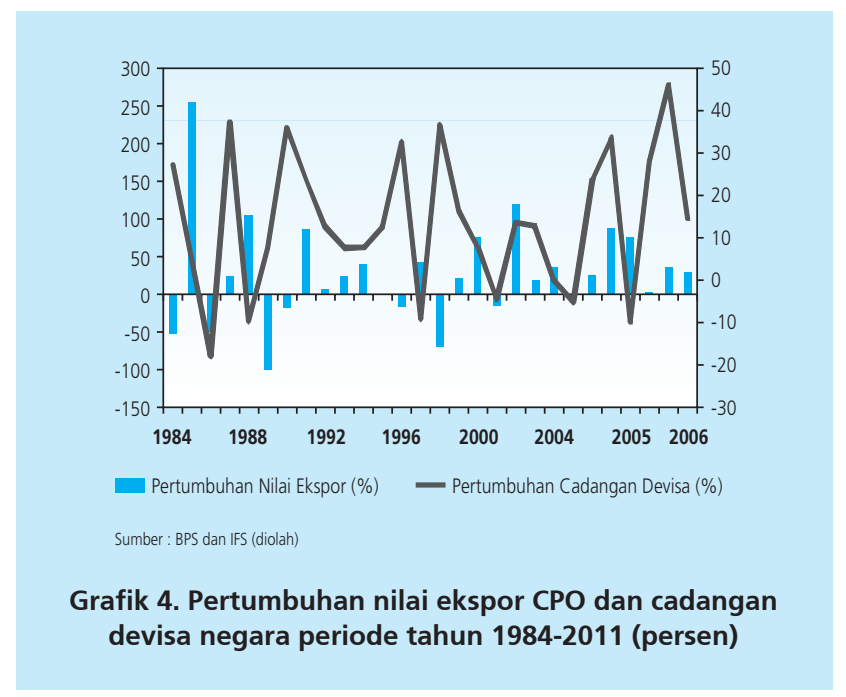

Sebagaimana terlihat pada grafik 4, pertumbuhan nilai ekspor CPO cenderung diikuti oleh pertumbuhan cadangan devisa negara. Tahun 1991, terjadi lonjakan nilai ekspor CPO dua kali lipat dari tahun sebelumnya. Lonjakan ini disebabkan oleh peningkatan produksi dalam negeri sehingga meningkatkan volume ekspor. Melimpahnya produksi menjadi salah satu pemicu pertumbuhan nilai ekspor yang paling pesat selama beberapa dekade ini. Pada tahun 1985 pertumbuhan nilai ekspor mencapai presentase sebesar 255 persen dari tahun sebelumnya.

\subsection{Estimasi Persamaan Simultan}

Sebagaimana tersaji pada tabel 2, hasil estimasi dengan menggunakan Eviews 6.0 menunjukkan bahwa secara umum sebagian besar tanda koefisien dari variabel yang digunakan telah sesuai dengan yang diharapkan (sesuai dengan kriteria ekonomi). Secara statistik, model yang digunakan valid, ditunjukkan oleh nilai F-Statistik hampir semua persamaan struktural hasil estimasi signifikan pada taraf nyata 5 dan 10 persen, yang menunjukkan variabel-variabel penjelas yang digunakan pada setiap persamaan struktural secara simultan (bersama-sama) signifikan dalam mempengaruhi variabel tak bebas. Nilai Adjusted R-Squared dari persamaanpersamaan yang digunakan juga cukup besar, menunjukkan besarnya proporsi variasi dari 
variabel tak bebas yang bisa dijelaskan oleh variabel bebas di masing-masing model sudah baik. Model yang telah melewati tahapan pengujian asumsi dapat diinterpretasikan seperti yang dapat dilihat pada sub-bab berikutnya.

Model estimasi Weight Two Stage Least Square (WTSLS) digunakan untuk mengestimasi persamaan struktural pada penelitian ini. Hal ini dikarenakan melalui uji Lagrange Multiplier untuk struktur varians dan kovarians residual statistik dapat dibuktikan bahwa struktur varians dan kovarians dari residual model adalah heteroskedastik. Oleh karena itu digunakan estimasi ini untuk mengakomodasi terjadinya pendugaan yang tidak efisien akibat pelanggaran terhadap asumsi homoskedastisitas.

Sistem persamaan struktural yang digunakan pada model persamaan simultan ini telah lolos asumsi normalitas (Lampiran 2). Sedangkan untuk pengujian asumsi non-autokorelasi, penulis menggunakan statistik uji korelasi serial The Breusch-Godfrey Serial Correlation LM Test. Melalui uji ini semua model secara statistik dapat dinyatakan lolos asumsi non-autokorelasi. Model yang telah melewati tahapan pengujian asumsi dapat diinterpretasikan seperti yang dapat dilihat pada sub-bab berikutnya.

Hasil estimasi di bawah menggunakan estimasi Two Stage Least Squares untuk periode tahun 1984-2011. Hasil yang diperoleh sangat memuaskan, karena sebagian besar nilainya signifikan dan memiliki tanda yang sesuai dengan teori. Berikut adalah gambaran hubungan antar variabel yang diperoleh dari persamaan simultan di atas.

\begin{tabular}{|c|c|c|c|c|c|}
\hline \multicolumn{6}{|c|}{$\begin{array}{c}\text { Tabel } 2 \\
\text { Hasil Estimasi Persamaan Struktural dengan WTSLS }\end{array}$} \\
\hline $\begin{array}{l}\text { Persamaan } \\
\text { Struktural }\end{array}$ & $\begin{array}{l}\text { Variabel } \\
\text { Dependen }\end{array}$ & $\begin{array}{l}\text { Variabel } \\
\text { Independen }\end{array}$ & Koefisien & \multicolumn{2}{|c|}{ Ringkasan Statistik } \\
\hline (1) & (2) & (3) & (4) & \multicolumn{2}{|l|}{ (5) } \\
\hline \multirow[t]{4}{*}{1} & $\widehat{\operatorname{LnM}}$ & C & $\begin{array}{c}-1,735475^{*} \\
(0.0297)\end{array}$ & & \\
\hline & & & $\begin{array}{r}0,875031^{*} \\
(0.0000)\end{array}$ & R-Squared & 0,996899 \\
\hline & & LnDeh & $\begin{array}{l}0,063493 \\
(0.3400)\end{array}$ & Adjusted R-Squared & 0,996512 \\
\hline & & (LnRER+LnPc) & $\begin{array}{r}0,184368^{*} \\
(0.0082)\end{array}$ & Prob(F-statistic) & 0,000000 \\
\hline \multirow[t]{2}{*}{ II } & $\widehat{P}$ & $\mathrm{C}$ & $\begin{array}{r}-18,33213^{*} \\
(0.0010)\end{array}$ & & \\
\hline & & LnM & $\begin{array}{r}0,263076^{*} \\
(0.0076)\end{array}$ & R-Squared & 0,947881 \\
\hline
\end{tabular}




\begin{tabular}{|c|c|c|c|c|c|}
\hline \multirow{3}{*}{$\begin{array}{l}\text { Persamaan } \\
\text { Struktural }\end{array}$} & \multirow{3}{*}{$\begin{array}{l}\text { Variabel } \\
\text { Dependen }\end{array}$} & \multirow{2}{*}{$\begin{array}{c}\text { Variabel } \\
\text { Independen } \\
\mathrm{Y}\end{array}$} & \multirow{2}{*}{$\begin{array}{c}\text { Koefisien } \\
3,922524^{*} \\
(0.0152)\end{array}$} & \multicolumn{2}{|c|}{ Ringkasan Statistik } \\
\hline & & & & Adjusted R-Squared & 0,941366 \\
\hline & & (LnRER+Pw) & $\begin{array}{c}1,385982^{*} \\
(0.0053)\end{array}$ & Prob(F-statistic) & 0,000000 \\
\hline \multirow[t]{6}{*}{ III } & $L \widehat{n R E R}$ & C & $\begin{array}{l}0.834307 \\
(0.7688)\end{array}$ & & \\
\hline & & $P$ & $\begin{array}{c}-0,402487^{*} \\
(0.0451)\end{array}$ & R-Squared & 0,868839 \\
\hline & & $P^{*}$ Dummy & $\begin{array}{c}-1,100307^{*} \\
(0.0000)\end{array}$ & Adjusted R-Squared & 0,839030 \\
\hline & & Pw & $\begin{array}{c}2,352700^{*} \\
(0.0057)\end{array}$ & Prob(F-statistic) & 0,000000 \\
\hline & & LnPc & $\begin{array}{c}-0,149984^{*} \\
(0.0232)\end{array}$ & & \\
\hline & & Dummy & $\begin{array}{c}5,334751^{*} \\
(0.0000)\end{array}$ & & \\
\hline
\end{tabular}

\section{Pengaruh Harga CPO Dunia Terhadap Pertumbuhan Uang Beredar}

Peningkatan permintaan dunia akan komoditas CPO dan turunannya telah mempengaruhi perekonomian negara-negara penghasil CPO dunia, seperti halnya Indonesia dan Malaysia. Permintaan CPO di pasar internasional yang semakin meningkat untuk kebutuhan pangan maupun produksi biodiesel membuat ekspor CPO Indonesia cenderung meningkat.

Sebagai komoditas ekspor utama, perubahan harga dunia CPO diduga memiliki pengaruh terhadap sektor moneter di Indonesia, yang nantinya akan berakibat pada perubahan perilaku nilai tukar riil. Berikut ini akan dijelaskan mekanisme perubahan harga CPO dunia yang dapat mempengaruhi sektor moneter, yaitu melalui pertumbuhan uang beredar. Model yang dibangun ini dapat menjelaskan keragaman perubahan pertumbuhan uang sebesar 99,68 persen, sementara 0,32 persen lainya dipengaruhi oleh faktor lain di luar model.

Pada tabel 8 di atas terlihat bahwa pertumbuhan uang lag pertama berpengaruh signifikan terhadap pertumbuhan uang pada taraf 5 persen secara positif sebesar 0,875031. Artinya jika pertumbuhan uang lag pertama meningkat sebesar sepuluh persen maka pertumbuhan uang saat ini akan meningkat sebesar 8,75031 persen dengan asumsi variabel lain konstan. Hal ini mengindikasikan peningkatan kebutuhan masyarakat dari tahun ke tahun terus meningkat. Manusia pada dasarnya tidak pernah puas dengan sesuatu yang telah dimilikinya, sehingga pertumbuhan uang beredar periode tahun sebelumnya diduga dapat meningkatkan kebutuhan 
masyarakat terhadap uang saat ini. Hal serupa juga terjadi di Kolumbia, sebagaimana hasil penelitian yang dilakukan oleh Sebastian Edwards (1987), ia juga membuktikan pengaruh positif dari tiga lag pertama pertumbuhan uang beredar terhadap pertumbuhan uang beredar saat ini.

Pengaruh defisit anggaran terhadap pertumbuhan uang secara statistik tidak signifikan, namun tanda koefisiennya sesuai dengan teori ekonomi. Hasil ini sesuai dengan penelitian yang dilakukan oleh Nanang Adrian (2010). Hal ini dapat dijelaskan pertama, karena adanya UU No.17/2003 tentang Keuangan Negara defisit APBN dan APBD secara kumulatif tidak boleh melampaui batas 3 persen terhadap PDB. Mengecilnya proporsi defisit fiskal terhadap PDB mengakibatkan semakin kecil nilai defisit fiskal sehingga untuk menutupi kekurangannya dapat dilakukan dengan penciptaan uang, maupun utang luar negeri yang besarnya tidak menambah jumlah uang beredar secara signifikan.

Kedua, sejak tahun 2000 transmisi pengaruh defisit anggaran terhadap variabel moneter melalui jalur moneter secara institusional berubah. Sejak UU No. 23 Tahun 1999 diberlakukan, BI tidak diperbolehkan memberikan dana talangan terhadap pengeluaran pemerintah dan atau bahkan membiayai defisit rekening pemerintah di BI (Maryatmo, 2004). Dana talangan ini dapat mempunyai konsekuensi meningkatkan uang inti dan akhirnya mempengaruhi jumlah uang beredar.

Dalam persamaan ini, pertumbuhan nilai tukar riil dan harga CPO dunia memiliki koefisien yang sama. Kedua variabel ini berpengaruh signifikan pada taraf 5 persen dan bernilai negatif sebesar 0,18436. Artinya, jika terjadi pertumbuhan nilai tukar atau harga dunia CPO sebesar 10 persen maka pertumbuhan uang akan mengalami peningkatan sebesar 1,8436 persen.

Indonesia mengekspor CPO mentah relatif lebih besar dibandingkan Malaysia untuk keperluan bahan baku antara untuk industri pangan dan non pangan, dan untuk kebutuhan CPO derivat lebih banyak dipenuhi oleh Malaysia. Ekspor CPO merupakan salah satu penyumbang devisa terbesar negara. Menurut M. Nosihin dalam Prayitno (2002) dikatakan bahwa penerimaan yang diterima pemerintah dalam bentuk valuta asing yang kemudian ditukarkan dengan rupiah, maka dalam proses pertukaran ini, akan meningkatkan cadangan aktiva Bank Indonesia dan jumlah uang beredar bertambah dengan jumlah uang yang sama. Jadi antara cadangan devisa dan jumlah uang beredar hubungannya cukup erat, dimana jumlah cadangan devisa yang ditukarkan menambah jumlah uang beredar dalam jumlah yang sama.

Penurunan nilai mata uang rupiah terhadap mata uang asing menyebabkan harga CPO dalam mata uang asing akan menguat, dengan demikian produsen akan melakukan penjualan CPO ke pasar internasional dalam upaya mengejar devisa negara. Selain itu, karena barangbarang domestik relatif lebih murah maka penduduk domestik hanya akan membeli sedikit barang impor. Akibatnya, jumlah ekspor neto meningkat. Hal ini sesuai dengan penelitian yang dilakukan oleh Zuhroh dan Kaluge (2007), depresiasi nilai tukar riil dapat memperbaiki neraca perdagangan dalam jangka panjang. Perbaikan neraca berjalan ini tentu akan diikuti 
oleh peningkatan cadangan devisa, yang selanjutnya meningkatkan jumlah uang beredar di masayarakat.

Menurut Sebastian Edward (1987), nilai tukar riil dan harga dunia merupakan faktor yang paling berpengaruh terhadap perubahan harga domestik suatu komoditas, sehingga penjumlahan kedua variabel ini juga dapat diartikan sebagai pertumbuhan harga domestik. Berdasarkan hasil estimasi di atas, dapat pula diartikan bahwa pertumbuhan harga domestik CPO secara signifikan berpengaruh positif terhadap pertumbuhan uang beredar. Peningkatan harga domestik terhadap CPO akan meningkatkan kebutuhan masyarakan akan uang nominal.

Pertumbuhan jumlah uang beredar yang terjadi secara wajar akan memberikan pengaruh positif terhadap pertumbuhan ekonomi, namun pertumbuhan yang drastis akan menyebabkan inflasi yang tentunya memberikan efek negatif. Oleh sebab itu, variabel yang memiliki hubungan proaktif terhadap jumlah uang beredar seperti halnya nilai tukar riil dan defisit anggaran harus dijaga kestabilannya agar pertumbuhan uang beredar dapat terjadi secara wajar.

Sementara itu, harga CPO dunia tidak dapat distabilkan oleh pemerintah, karena perdagangan dunia masih menggunakan harga yang distandarkan di Malaysia dan Rotterdam. Sehingga untuk mengatasi tingginya ekspor CPO karena peningkatan harga, maka diperlukan pajak khusus bagi ekpostir CPO. Pemberlakuan pajak yang tinggi dapat mengurangi tingginya ekspor, sehingga permintaan domestik terhadap CPO pun masih dapat terpenuhi.

\section{Pengaruh Pertumbuhan Uang Beredar Terhadap Inflasi}

Berdasarkan tabel 8, inflasi secara signifikan dipengaruhi oleh variabel pertumbuhan uang beredar, pertumbuhan ekonomi dan pertumbuhan harga barang tradable dunia pada tingkat signifikansi 5 persen. Model ini dapat menjelaskan 94,13 persen keragaman inflasi, sementara 5,87 persen sisanya dijelaskan oleh variabel lain yang tidak terdapat dalam model.

Pertumbuhan uang secara signifikan dan positif mempengaruhi inflasi sebesar 0,263076. Artinya, ketika terjadi pertumbuhan uang beredar sebesar 10 persen maka inflasi akan meningkat sebesar 2,63 persen. Dalam teori kuantitas uang, ditunjukkan bahwa jika jumlah uang beredar meningkat, maka akibatnya dapat dilihat dari ketiga variabel lainnya: harga naik, kuantitas output naik, atau kecepatan perputaran uang turun. Hal ini mendukung penelitian yang dilakukan oleh Yusni Maulida, Mardiana, dan Anthoni Mayes (2010), yang menyatakan bahwa hubungan antara pertumbuhan uang dan inflasi adalah positif.

Saat Bank Sentral mengubah jumlah uang beredar (M) dan menyebabkan perubahan proporsional terhadap nilai output nominal (PY), perubahan tersebut akan tercermin dalam tingkat harga (P). Karena tingkat inflasi ditunjukkan oleh perubahan persentase dalam tingkat harga, maka meningkatnya jumlah uang beredar akan menyebabkan inflasi. 
Selanjutnya, pertumbuhan ekonomi memiliki pengaruh signifikan dan positif terhadap inflasi sebesar 3,92 persen. Ketika terjadi pertumbuhan ekonomi sebesar 1 persen maka inflasi akan meningkat sebesar 3,92 persen. Hasil yang diperoleh ini sesuai dengan harapan peneliti bahwa untuk memacu pertumbuhan ekonominya suatu negara harus meningkatkan inflasinya. Begitu pula hasil yang diperoleh oleh Syaiful Muqrobi (2011), pertumbuhan ekonomi dan inflasi memiliki hubungan dua arah yang positif.

Berikutnya, depresiasi nilai tukar dan inflasi dunia memiliki pengaruh yang sama terhadap inflasi. Dalam model, kedua variabel ini memiliki koefisien yang sama, yaitu sebesar 1,38. Artinya pertumbuhan nilai tukar (depresiasi) atau inflasi dunia sebesar 1 persen akan meningkatkan inflasi dalam negeri sebesar 1,38. Menurut Sebastian Edward (1987), penjumlahan kedua variabel ini dapat menggambarkan perubahan harga barang tradable dunia. Sehingga dapat juga diartikan pertumbuhan harga barang tradable dunia, menyebabkan inflasi dalam negeri sebesar 1,32. Hal ini sangat rasional, mengingat peningkatan harga barang impor merupakan salah satu penyebab terjadinya inflasi.

Dalam transmisi kebijakan moneter, nilai tukar merupakan salah satu jalur yang dapat menjelaskan perubahan tingkat harga pada suatu periode selain pertumbuhan jumlah uang yang beredar. Pergerakan nilai tukar dapat mempengaruhi penawaran dan permintaan agregat, yang selanjutnya berdampak pada output dan harga. Besar kecilnya pengaruh pergerakan nilai tukar terhadap tingkat harga sangat ditentukan oleh sistem nilai tukar yang dianut suatu negara. Dalam sistem nilai tukar mengambang terkendali, kebijakan moneter ekspansif oleh bank sentral akan mendorong depresiasi mata uang domestik dan meningkatkan harga barang impor, yang selanjutnya akan mendorong kenaikan harga barang domestik, walaupun tidak terdapat ekspansi di sisi permintaan agregat. Hal ini yang disebut sebagai dampak langsung dari pergerakan nilai tukar (direct passthrough) dan jika pengaruh perubahan nilai tukar melalui perubahan permintaan agregat disebut sebagai dampak tidak langsung (indirect passthrough).

Berdasarkan asalnya inflasi dibedakan menjadi: (1) Inflasi yang berasal dari dalam negeri (domestic inflation), dan (2) Inflasi yang berasal dari luar negeri (foreign inflation). Inflasi yang berasal dari dalam negeri biasanya timbul karena defisit anggaran belanja yang dibiayai dengan pencetakan uang baru, gagal panen, bencana alam, perubahan kebijakan harga pemerintah, faktor musiman seperti perayaan hari besar keagamaan, tindakan spekulatif menimbun barang yang dapat mengganggu ketersediaan barang, serta ekspektasi masyarakat terhadap inflasi yang akan datang. Sedangkan inflasi yang berasal dari luar negeri adalah inflasi yang terjadi karena kenaikan harga-harga komoditi di luar negeri (di negara-negara mitra dagang) atau karena terjadinya depresiasi nilai tukar. Kenaikan harga barang-barang yang kita impor secara langsung mengakibatkan kenaikan indeks biaya hidup karena sebagian dari barang-barang yang tercakup di dalamnya berasal dari impor, dan secara tidak langsung menaikkan indeks harga melalui kenaikan biaya produksi dari berbagai barang yang menggunakan bahan baku atau mesin-mesin yang diimpor. 
Dengan diketahuinya beberapa variabel yang memiliki pengaruh terhadap pergerakan inflasi, maka pengendalian inflasi dapat dilakukan melalui variabel-variabel tersebut. Seperti yang telah dijelaskan sebelumnya, bahwa peredaran uang dalam masyarakat dapat dijaga jumlahnya. Sementara penyebab inflasi lainnya seperti pertumbuhan ekonomi dapat distabilkan oleh pemerintah. Pendorong utama pertumbuhan ekonomi di Indonesia adalah tingginya konsumsi , sehingga perlu untuk mengontrol konsumsi domestik. Indonesia saat ini menganut rezim nilai tukar mengambang bebas, sehingga untuk kestabilan nilai tukar riil pemerintah tidak dapat berperan langsung akan tetapi secara tidak langsung mengontrol variabel makro lain yang merupakan penyebab depresiasi nilai tukar riil.

\section{Dampak Inflasi Terhadap Nilai Tukar Riil Rupiah}

Berdasarkan model ini, pertumbuhan nilai tukar rupiah secara signifikan dipengaruhi oleh inflasi, inflasi dunia, pertumbuhan harga CPO, sistem nilai tukar yang dianut, dan inflasi pada saat Indonesia menganut sistem nilai tukar bebas mengambang dengan taraf signifikansi 5 persen. Selanjutnya, model ini dapat menjelaskan keragamana dari pertumbuhan nilai tukar sebesar 83,76 persen sementara 16,24 persen sisanya dijelaskan oleh variabel lain yang tidak ada dalam model.

Hubungan negatif antara nilai tukar riil dan inflasi telah memenuhi logika ekonomi yang akan dijelaskan sebagai berikut. Menurut Muqrobi (2011), terjadinya inflasi akan menurunkan pertumbuhan output. Penurunan pertumbuhan output (pendapatan menurun) ini selanjutnya akan mengurangi impor dan mengurangi dorongan permintaan valas sehingga rupiah akan mengalami apresiasi. Berdasarkan hasil estimasi, dapat diinterpretasikan bahwa peningkatan inflasi sebesar 1 persen akan menurunkan pertumbuhan nilai tukar (apresiasi) sebesar 0,34 persen. Hasil ini didukung oleh penelitian yang dilakukan oleh Victor E. Oriavwote dan Samuel J. Eshanake (2012) yang menyatakan bahwa inflasi akan mengakibatkan nilai tukar riil terapresiasi.

Inflasi yang terjadi pada saat Indonesia menganut sistem nilai tukar mengambang bebas ternyata memiliki pengaruh yang signifikan dan negatif terhadap pertumbuhan nilai tukar. Bahkan, pengaruhnya lebih besar daripada pengaruh dari inflasi secara umumnya. Saat terjadi inflasi pada rezim nilai tukar mengambang bebas, nilai tukar akan mengalami apresiasi dengan penurunan pertumbuhan nilai tukar sebesar 1,39. Hal ini mengindikasikan kuatnya peranan inflasi dalam perubahan nilai tukar pada rezim nilai tukar mengambang bebas. Beralihnya sistem nilai tukar Indonesia dari nilai tukar mengambang terkendali menjadi mengambang bebas membawa dampak yang besar bagi perekonomian Indonesia. Selain itu, nilai tukar rupiah menjadi sangat rentan terhadap perubahan perekonomian seperti peningkatan inflasi.

Berbeda halnya dengan inflasi domestik, inflasi dunia memiliki hubungan positif terhadap nilai tukar sebesar 2,89 persen. Ketika terjadi peningkatan inflasi dunia sebesar 1 persen, maka 
nilai tukar akan tumbuh (depresiasi) sebesar 2,89 persen. Hasil serupa juga dikemukakan oleh Sebastian Edward (1987) bahwa inflasi dunia dapat menyebabkan nilai tukar riil dalam negeri terdepresiasi.

Menurut persamaan Fisher, kenaikan satu persen dalam tingkat inflasi sebaliknya menyebabkan kenaikan satu persen dalam tingkat bunga nominal. Bila inflasi tinggi, tingkat bunga nominal biasanya tinggi (Mankiw, 2007). Sehingga apabila inflasi dunia tinggi, maka suku bunganya juga akan lebih tinggi dari Indonesia. Menurut BI, perubahan suku bunga nantinya dapat mempengaruhi nilai tukar. Mekanisme ini sering disebut jalur nilai tukar. Kenaikan suku bunga akan mendorong kenaikan selisih antara suku bunga di luar negeri dengan suku bunga Indonesia. Dengan melebarnya selisih suku bunga tersebut mendorong investor Indonesia untuk menanamkan modal ke dalam instrumen-instrumen keuangan di luar negeri karena mereka akan mendapatkan tingkat pengembalian yang lebih tinggi. Aliran modal keluar ini pada gilirannya akan mendorong depresiasi nilai tukar rupiah.

Nilai tukar salah satunya dipengaruhi oleh kegiatan perdagangan internasional.CPO merupakan komoditi unggulan ekspor nonmigas di Indonesia dimana pada tahun 2011 kontribusi ekspor CPO terhadap ekspor nonmigas diperkirakan tumbuh sebesar 16 persen. Harga CPO dunia memiliki pengaruh signifikan dan negatif terhadap nilai tukar sebesar 0,2 persen. Artinya, pertumbuhan harga CPO dunia sebesar 10 persen akan menurunkan pertumbuhan (apresiasi) nilai tukar sebesar 2 persen. Peningkatan harga CPO akan meningkatkan permintaan rupiah dari negara importir, sehingga nilai rupiah akan terapresiaisi. Hasil ini juga didukung oleh penelitian Sebastian Edward (1987), peningkatan harga komoditas ekspor yaitu kopi di Kolumbia menyebabkan nilai tukar riil dalam negeri terapresiasi.

Penelitian ini dilakukan dari tahun 1984 hingga 2011, artinya pada periode tersebut telah terjadi dua kali pergantian sistem nilai tukar yaitu sistem nilai tukar mengambang terkendali dan sistem nilai tukar mengambang bebas. Sistem nilai tukar terkendali diberlakukan hingga tahun 1997, kemudian pemerintah menggantinya dengan sistem nilai tukar mengambang bebas hingga saat ini. Dari hasil penelitian memperlihatkan dummy yang digunakan signifikan dan memiliki koesfisien sebesar 6,44. Artinya pertukaran sistem nilai tukar memiliki pengaruh yang signifikan terhadap pertumbuhan nilai tukar, pada saat diberlakukan sistem nilai tukar mengambang bebas, nilai tukar riil tumbuh hingga 6,44 persen. Pada rezim kurs mengambang bebas, kurs dibiarkan berfluktuasi dengan bebas untuk menanggapi kondisi perekonomian yang sedang berubah (Mankiw, 2007). Akibatnya, perubahan kurs akan lebih berfluktuatif.

Dalam sistem nilai tukar mata uang mengambang bebas, nilai tukar mata uang ditentukan oleh mekanisme pasar tanpa intervensi dari pemerintah. Berbeda dengan sistem nilai tukar mata uang mengambang terkendali, dengan sistem nilai tukar mata uang mengambang bebas fluktuasi nilai mata uang dibiarkan sehingga nilainya sangat fleksibel. Dalam sistem ini, otoritas moneter diberikan keleluasaan untuk menerapkan kebijakan moneter secara independen tanpa harus memelihara nilai tukar mata uang domestik terhadap mata uang asing pada nilai tertentu. 
Sehingga, nilai tukar mata uang menjadi lebih sensitif. Pada sistem ini, nilai tukar ditentukan oleh mekanisme pasar. Artinya peranan harga komoditi di pasar internasional semakin besar dalam perubahan nilai tukar tukar riil suatu negara.

\section{Analisis Pengaruh Harga CPO Dunia Terhadap Nilai Tukar Riil}

Ketiga persamaan struktural yang dibangun dalam penelitian ini membentuk suatu sistem. Sehingga perubahan pada satu variabel eksogen tertentu akan mengubah semua nilai variabel endogennya. Setelah melakukan analisis terhadap masing-masing persamaannya, maka sekarang akan dilakukan analisis terhadap keseluruhan sistem yang dibangun oleh persamaanpersamaan tersebut.

Hasil penelitian menunjukkan bahwa harga CPO dunia dapat mempengaruhi nilai tukar riil baik secara langsung maupun melalui sektor moneter. Dari persamaan struktural ketiga dapat dilihat bahwa pertumbuhan harga CPO memiliki koefisien negatif dan signifikan terhadap pertumbuhan nilai tukar riil.

Kemudian pengaruhnya melalui sektor moneter dapat dijelaskan melalui ketiga persamaan tersebut.Pada persamaan struktural pertama terlihat bahwa dengan tingkat signifikansi sebesar 5 persen, pertumbuhan harga CPO dunia dapat meningkatkan pertumbuhan uang beredar pada saat kondisi cateris paribus.

Peningkatan harga CPO dunia secara tidak langsung memicu inflasi. Hal ini dikarenakan dengan peningkatan harga CPO dunia, jumlah uang beredar akan semakin tinggi, dimana peningkatan jumlah uang beredar ini secara langsung menyebabkan inflasi. Dari persamaan struktural kedua, dengan tingkat signifikansi sebesar 5 persen, pertumbuhan uang beredar sebesar 1 persen akan menyebabkan inflasi sebesar 0,26 persen. Namun perlu diingat bahwa hal ini terjadi pada saat kondisi cateris paribus. Pertumbuhan uang bukanlah satu-satunya penyebab terjadinya inflasi, perubahan variabel makro lain seperti pertumbuhan ekonomi juga dapat mempengaruhi inflasi.

Pada akhirnya, pertumbuhan harga CPO dunia secara tidak langsung dapat menyebabkan nilai tukar riil terapresiasi. Dengan tingkat signifikansi sebesar 5 persen, tingkat inflasi pada persamaan struktural ketiga akan menurunkan tingkat pertumbuhan nilai tukar riil atau akan terjadi apresiasi nilai tukar riil rupiah. Namun, perlu diketahui bahwa peningkatan inflasi yang terlalu drastis hanya akan membawa dampak buruk bagi perekonomian. Sehingga perlu dikontrol agar inflasi yang terjadi tetap pada batasan yang normal.

\section{Elastisitas Harga CPO Dunia Terhadap Perubahan Nilai Tukar Riil}

Tabel 3 di bawah ini menunjukkan hasil simulasi berdasarkan pertumbuhan harga CPO dunia sebesar sepuluh persen. Pertumbuhan LnPc sebesar sepuluh persen berdampak kepada 
peningkatan dan penurunan variable endogen. Perubahan terbesar terjadi pada variabel nilai tukar riil, di mana pertumbuhan harga CPO dunia sebesar sepuluh persen akan mengakibatkan nilai tukar riil turun sebesar 1,2 persen. Artinya saat harga CPO dunia meningkat, nilai tukar riil rupiah akan terapresiasi. Dengan meningkatnya harga CPO dunia, maka nilai ekspor juga akan meningkat sehingga akan meningkatkan cadangan devisa. Membengkaknya cadangan devisa mengakibatkan jumlah uang beredar tumbuh sebesar 0,68 persen. Hal ini dapat menyebabkan kinerja moneter terekspansi melebihi kapasitas produksi ekonomi yang berakhir pada inflasi sebesar 0,97 persen. Inflasi yang terjadi pada saat sistem nilai tukar mengambang bebas ini yang pada akhirnya yang akan menghasilkan apresiasi terhadap nilai tukar. Di lain sisi, peranan cadangan devisa sendiri (Bank Indonesia) salah satunya adalah sebagai kebutuhan likuiditas untuk mempertahankan stabilitas nilai tukar. Dari jalur ini serta besarnya pengaruh harga CPO dunia terhadap pergerakan nilai tukar, pada ahirnya menyebabkan apresiasi nilai tukar.

\begin{tabular}{c|c|c|c|c}
\multicolumn{6}{c}{ Tabel 3 } \\
\hline No & Endogenous & Baseline & Hasil Simulasi & $\Delta \%$ \\
\hline $\mathbf{1})$ & $\mathbf{( 2 )}$ & $\mathbf{( 3 )}$ & $\mathbf{( 4 )}$ & $\mathbf{( 5 )}$ \\
\hline $\mathbf{1}$ & LnM & 12,7668 & 12,8539 & 0,68224 \\
\hline $\mathbf{2}$ & $\mathrm{P}$ & 3,8111 & 3,8482 & 0,97347 \\
\hline $\mathbf{3}$ & LnRer & 8,9899 & 8,8818 & $-1,2025$ \\
\hline
\end{tabular}

Dengan simulasi pertumbuhan harga CPO dunia sebesar 20 persen akan memberikan dampak yang ambigu bagi perekonomian Indonesia, terutama terhadap apresiasi nilai tukar dan inflasi. Seperti yang terlihat pada tabel 4, penurunan pertumbuhan nilai tukar riil dapat terjadi hingga mencapai 2,49 persen. Dengan demikian, dapat kita ketahui bahwa semakin tinggi harga CPO maka semakin kuat pula nilai tukar riil rupiah.

Berdasarkan model persamaan simultan yang dihasilkan sebelumnya, peningkatan pertumbuhan harga CPO awalnya mempengaruhi pertumbuhan uang beredar. Disini dapat dilihat terjadi pertumbuhan uang beredar sebesar 1,4 persen. Meningkatnya nilai ekspor CPO akan meningkatkan cadangan devisa, dimana peningkatan cadangan devisa akan meningkatkan uang beredar. Kemudian, semakin banyak uang beredar maka harga barang-barang akan meningkat secara umum sehingga inflasi meningkat 1,611 persen. Untuk memperbaiki pengaruh buruk inflasi dan untuk menaikkan daya saing (competitiveness) produk lokal, maka suatu negara menurunkan harga barang di pasar luar negeri dan pada waktu yang sama meningkatkan pada tingkat tertentu nilai mata uangnya sendiri. Sehingga inflasi ini menyebabkan apresiasi nilai 
tukar yang lebih tinggi. Begitu pula dengan pengaruh tingkat harga CPO dunia menyebabkan turunnya pertumbuhan nilai tukar.

\begin{tabular}{c|c|c|c|c}
\multicolumn{7}{c}{ Tabel 4 } \\
\hline No & Endogil Simulasi Pertumbuhan Harga CPO Dunia Sebesar 20 Persen (Persen) \\
\hline $\mathbf{1})$ & $\mathbf{( 2 )}$ & Baseline & Hasil Simulasi & $\Delta \%$ \\
\hline $\mathbf{1}$ & LnM & $\mathbf{( 3 )}$ & $\mathbf{( 4 )}$ & $\mathbf{( 5 )}$ \\
\hline $\mathbf{2}$ & $\mathrm{P}$ & 3,7668 & 12,9462 & 1,4052 \\
\hline $\mathbf{3}$ & LnRer & 8,8111 & 3,8725 & 1,6111 \\
\hline
\end{tabular}

\section{KESIMPULAN DAN SARAN}

Berdasarkan penelitian di atas, dapat diketahui bahwa CPO merupakan komoditas unggulan subsektor perkebunan karena memiliki nilai ekonomis tinggi dan merupakan komoditas ekspor utama non migas. Sebagai komoditas unggulan, kenaikan tingkat harga CPO, baik secara langsung maupun melalui sektor moneter secara nyata terbukti dapat menyebabkan apresisasi nilai tukar riil. Kemudian, hasil simulasi model menunjukkan bahwa semakin tinggi pertumbuhan harga CPO dunia semakin tinggi pula inflasi dan semakin besar apresiasi nilai tukar riil.

Berdasarkan kesimpulan di atas, sebaiknya pemerintah melalui Kementrian Perdagangan RI dan seluruh stakeholder harus mengupayakan agar Indonesia dapat menjadi salah satu patokan harga CPO dunia dengan memindahkan transaksi perdagangan future market CPO dunia dari bursa berjangka di Malaysia ke bursa berjangka di Indonesia. Kemudian, pemerintah dapat mengupayakan pemberian insentif pada industri hilir CPO yang menghasilkan produk turunan CPO, seperti biodiesel, sehingga dapat mendorong para pengusaha untuk mengekspor produk turunan CPO yang memiliki nilai tambah yang lebih besar. Untuk penelitian selanjutnya, peneliti menyarankan untuk melihat pengaruh produk olahan CPO terhadap perekonomian Indonesia. 


\section{DAFTAR PUSTAKA}

Andrian, Nanang.(2011). Defisit Anggaran, Pertumbuhan Uang dan Inflasi di Indonesia [Skripsi]. Bogor : Institut Pertanian Bogor.

Boediono.(1993). Ekonomi Makro.Edisi ke-4.Yogyakarta : BPFE UGM.

BPS.(2008). Kajian Komoditas Unggulan. Jakarta: BPS.

BPS. (2013). Produk Domestik Bruto Atas Dasar Harga Berlaku Menurut Lapangan Usaha (Miliar Rupiah), 2004-2012. http://www.bps.go.id/tab sub/view.php?kat=2\&tabel=1\&daftar=1\&id subyek=11\&notab=1. [1 Juli 2013].

Cashin, Paul, Luis F. Cespedes and Ratna Sahay (2004). Commodity Currencies and the Real Exchange Rate. Journal of Development Economics, Elsevier, 75(1).

Chen, Yu-chin and Kenneth Rogoff (2003). Commodity Currencies. Journal of International Economics, Elsevier, 60(1).

Dornbush, Fischer \& Startz, Richard. (2001). Makroekonomi. $8^{\text {th }}$ Edition. Jakarta : PT. Media Global Edukasi.

Frankel, Jeffrey (2007). On The Rand: Determinants Of The South African Exchange Rate. South African Journal of Economics, Economic Society of South Africa, 75, 3.

Edward, Sebastian. (1987). Commodity Export Price and the Real Exchange Rate in Development Country : Coffee in Columbia. Economic Adjustment and Exchange Rates in Developing Countries.12 Februari 2013. http://www.nber.org/books/edwa86-1.

E. Oriavwote, Victor and J. Eshanake, Samuel. (2012). Real Exchange Rate and Inflation: An Empirical Assessment of the Nigerian Experience. Mediterranean Journal of Social Sciences, 3(3). [2 Mei 2013].

Gujarati, Damodar. (2004). Basic Econometrics.4 $4^{\text {th }}$ Edition. New York: The McGraw-Hill Companies, Inc.

Direktorat Jederal Perkebunan. (2008). Lintasan Tiga Puluh Tahun Pengembangan Kelapa Sawit. http://ditjenbun.deptan.go.id/budtanan/images/bagian \%20ii.pdf.[9 Juli 2013].

Lipsey, R. G., et al. (1995). Pengantar Makroekonomi. Edisi ke-10.Jilid 1. Wasana, Kirbrandoko, dan Budijanto [editor]. Jakarta : Bina RupaAksara.

Mankiw, N. Gregory. (2007). Teori Makro Ekonomi Terjemahan: Edisi Keenam. Jakarta : PT. Gelora Aksara Pertama.

Maryatmo, R. (2004). Dampak Moneter Kebijakan Defisit Angaran Pemerintah dan Anggaran Pemerintah dan Peranan Asa Nalar dalam Simulasi Model Makro-Ekonomi Indonesia 
(1983:1-2002:4).Buletin Ekonomi Moneter dan Perbankan.12 Juni 2013 www.bi.go.id/NR/ rdonlyres/2C2A167B-06E1.../fdampakmon1.pdf.

Maulida, Yusni, Merdiana dan Mayes, Anthonio. (2010). Pengaruh Defisit Anggaran, Jumlah Uang Beredar dan Independensi Bank Indonesia terhadap Inflasi. Pekanbaru : Universitas Riau.

Muqrobi, Syaiful dan Pujiati, Amin. (2011). Inflasi dan Pertumbuhan Ekonomi : Uji Kausalitas. Jurnal Dinamika Keuangan dan Perbankan, 3(1).

Ngandu, S. (2005). Mineral Prices and the Exchange Rate: what does the Literature say. HSRC: mimeo.

Prayitno, Lily et al. (Maret 2002). Fakto-Faktor Yang Berpengaruh Terhadap Jumlah Uang Beredar di Indonesia Sebelum dan Sesudah Krisis: Sebuah Analisis Ekonometrika. Jurnal Manajemen dan Kewirausahaan, 4(1).

Samuelson, Paul. A. dan Nordhaus, William D. (2004). Makroekonomi Edisi ke 17. Jakarta : Erlangga.

Sitepu, Rasidin Karo-karo dan Bonar M. Sinaga. (2006). Aplikasi Model Ekonometrika: Estimasi, Simulasi, dan Peramalan Menggunakan Program SAS. Program Studi Ilmu Ekonomi Pertanian. Sekolah Pascasarjana. Bogor : Institut Pertanian Bogor.

UNCTAD.(2013). Free Market Commodity Price, Annual.http://unctadstat.unctad.org/ ReportFolders/reportFolders.aspx. [3 Juni 2013].

Zuhroh, Idah dan Kaluge, David. (2007). Dampak Pertumbuhan nilai Tukar Riil terhadap Pertumbuhan Neraca Perdagangan Indonesia. Jurnal of Applied Indonesia Aconomic, $191 ;(1)$. 